\title{
Study of Relationship between PlasmaHomocysteine Levels andGestationalhypertension
}

\author{
Dr. V. Geetha ${ }^{1}$, Dr. P. Thilagavathy ${ }^{2}$ \\ ${ }^{1}$ Department OfObstetrics And Gynaecology, Coimbatore Medical College And Hospital/The Tamil Nadu \\ Dr.MGR Medical University, India \\ ${ }^{2}$ Department OfObstetrics And Gynaecology, Coimbatore Medical College And Hospital/The Tamil Nadu \\ Dr.MGR Medical University, India
}

\begin{abstract}
A case control study comprising of 111 participants with 50 cases and 61 controls was performed. A fasting sample of plasma homocysteine was obtained from all the cases and controls. Plasma homocysteine was measured using the Chemi luminescence immunoassay method. It was found that the mean plasma homocysteine levels were higher in hypertensive women and increased with severity of disease. If there was positive family history of cardiovascular disease then plasma homocysteine levels were found to be higher. Higher the SBP, DBP \& MAP values, higher were the levels of plasma homocysteine.Thus the study establishes the positive relationship between plasma homocysteine levels and gestational hypertension. Increased levels of plasma homocysteine in pregnant women could be used as a potential marker for predicting gestational hypertension and its severity.
\end{abstract}

Keywords:DVT, GestationalHypertension,Mean arterial pressure, Plasma Homocysteine, Preeclampsia

\section{Introduction}

Hypertensive disorders are the most common medical complication of pregnancy with a reported incidence between 5 and 10 percent. The term hypertension in pregnancy is commonly used to describe a wide spectrum of patients who may have only mild elevations in blood pressure or severe hypertension with various organ dysfunctions (1).Hypertensive disorders together with haemorrhage and infection form a deadly triad that contribute greatly to maternal morbidity and mortality. In India, it accounts for $24 \%$ of all maternal deaths. It is also a major cause of preterm birth, intrauterine growth restriction and perinatal mortality. The underlying pathophysiological mechanisms of gestational hypertension appear between 8-18 weeks of gestation.Homocysteine is atherogenic and thrombophilic. Elevated homocysteine levels are implicated in coronary, cerebro vascular and peripheral arterial disease, DVT and preeclampsia. It has been proved that homocysteine has a definite role in the setting of gestational hypertension $(2,3)$.With this background this study aims at finding the relationship between plasma homocysteine and gestational hypertension.

2.1Aim:

\section{Aims And Objectives}

This study is designed to find out the relationship between plasma homocysteine levels and occurrence of gestational hypertension.

\subsection{Objectives:}

- To compare plasma homocysteine levels in both the groups.

- To establish a relationship between plasma homocysteine and gestational hypertension.

- To find out possible factors that might influence plasma homocysteine levels in hypertensive disorders of pregnancy.

\section{Materials And Methods}

Our study was a case control studyand enrolled 111 patients after obtaining informed consent, during the period January 2015 to December 2015 in Department of Obstetrics and Gynaecology, Coimbatore medical college hospital, Coimbatore. The cases of our study were postnatal patients who had gestational hypertension. The controls were postnatal patients who were comparable with the patients' groups with regard to social class, geographical area and age.

Gestational hypertension was defined as systolic BP> 140mm Hg \& diastolic BP> 90mm Hg detected for the first time during pregnancy after 20 weeks of gestation. Preeclampsia was defined as gestational hypertension with proteinuria. Eclampsia defined as seizures that cannot be attributed to other causes in a women with preeclampsia. Proteinuria is defined as $>1+$ dipstick. Conventional sphygmomanometer was usedfor 
the measurement of blood pressure. Korotkoff phase $\mathrm{V}$ was used to define diastolic pressure. Two measurements at least 6 hours apart were taken. Mean arterial pressure is defined as systolic BP $+2 / 3$ diastolic BP.

The users of vitamin B, folic acid, pharmacologic agents, women with disorder like chronic hypertension, diabetes mellitus, gastrointestinal, endocrine disorder, twin pregnancies were excluded from our study. The study group consisted of 50 cases and 61 controls. Of the cases 16, had gestational hypertension, 26 had preeclampsia and 8 had eclampsia. Controls had uncomplicated obstetric histories. The participants were subjected to detailed history elicitation \& physical examination.

Peripheral blood sample was sample was obtained from all participants in fasting state within a day of delivery. The plasma homocysteine was quantified with Chemi-luminescence immunoassay method. The normal range was between 5 and $15 \mu \mathrm{mol} / \mathrm{L}$.

\section{Results And Analysis}

The mean age of the patients enrolled in the study was $23.59 \pm 3.6$ years. The systolic blood pressure was in the range of $110-180 \mathrm{~mm} \mathrm{Hg}$ and diastolic blood pressure $70-130 \mathrm{~mm} \mathrm{Hg}$ with an average of 133.6 $\pm 17.7 / 89 \pm 15.5 \mathrm{mmHg}$. Mean arterial pressure of 111 patients included in the study was in the range 83.33 and 176.67 with a mean value of $104.5 \pm 15.1 \mathrm{mmHg}$. The average birth weight of the babies born to the patients included in the study was $2.8 \pm 0.4 \mathrm{Kg}$. Finally, the plasma homocysteine levels measured in the patients were in the range of $6-54$ with a mean value of $14.32 \pm 7.9 \mu \mathrm{mol} / \mathrm{L}$.

In our study, majority of the patients were in the age group of $<25$ years (84), of which $42.8 \%$ were found to be hypertensive. On the other hand, 5 patients were more than 30 years old, out of which $80 \%$ were found to be hypertensive. However, in the present study, the p value of association of age with gestational hypertension was found to be 0.523 and hence it is statistically insignificant.

In our study, out of 111 patients, $59.5 \%$ patients were primipara. Out of the 61 patients, $52.5 \%$ were primipara and the remaining $47.5 \%$ were found to be multiparous. 16 patients had gestational hypertension, $68.6 \%$ were primi and the remaining $31.3 \%$ were multiparous. Out of 26 preeclampsia patients $61.5 \%$ were primipara and the remaining $38.5 \%$ were multiparous. Out of 8 eclampsia patients $87.5 \%$ were found to be primi and $12.5 \%$ were found to be multiparous. The $\mathrm{p}$ value of association between parity and gestational hypertension in our study is 0.230 and hence found to be insignificant.

Out of 61 normotensive patients, $54.1 \%$ had 1 live child, $45.9 \%$ had more than 1 live birth. Out of 16 Gestational hypertensive patients, $18.8 \%$ had no live child. $43.8 \%$ had atleast 1 live child. $37.4 \%$ had more than 1 live child. Out of 26 preeclampsia patients, $3.8 \%$ had no live child and $65.4 \%$ had 1 live child and the remaining $30.8 \%$ had more than 1 living child. The $\mathrm{p}$ value indicating the association between the number of live birth and gestational hypertension is $<0.05 \%$ and hence there is a significant association between the two.

Out of 61 normotensive patients, $95.1 \%$ had no family history and the remaining $4.9 \%$ had family history of cardiovascular disease and gestational hypertension. In 16 gestational hypertension patients, $81.3 \%$ had no family history, $18.8 \%$ had a positive family history. Out of 26 preeclampsia patients, $57.7 \%$ had no family history, $42.3 \%$ had a family history. Out of 8 eclampsia patients, $62.5 \%$ had no family history and $37.5 \%$ had a significant family history. Hence, $\mathrm{p}$ value of this association is $<0.001$ which indicated a significant association between the family history of cardiovascular disease and gestational hypertension.

Out of 61 normotensive patients, only $6.6 \%$ had abnormal homocysteine levels. On the other hand, out of 16 gestational hypertensive patients $50 \%$ had abnormal homocysteine levels. Out of 26 preeclampsia patients $65.4 \%$ had abnormal homocysteine levels. Finally, out of 8 eclampsia patients $75 \%$ had abnormal homocysteine levels. The $\mathrm{p}$ value of this association is $<0.001$ and hence the association between the plasma homocysteine and gestational hypertension was found to be significant.

The correlation between various factors such as parity, family history of cardiovascular disease, systolic blood pressure, diastolic blood pressure, mean arterial pressure and plasma homocysteine levels were studied. It was found that there was no correlation between the parity and other factors. However, other factors excluding parity showed a positive correlation.

While analyzing the association between family history of cardiovascular disease and the abnormal plasma homocysteine levels, it was found that 20 patients out of the total 111 patients (18\%) had positive history of cardiovascular disease. Out of those 20 patients, it was found that 10 patients (50\%) had abnormal homocysteine levels. Hence, the Chi square value of family history of cardiovascular disease and plasma homocysteine levels is 3.854 and $\mathrm{p}<0.05$ which was statistically significant.

\section{Discussion}

Our study was conducted in the Departmentof Obstetrics and Gynaecology, Coimbatore medical college hospital, Coimbatore, with the aim of finding a relationship between plasma homocysteine levels and gestational hypertension with 111 participants 
The mean age in the control group was 23.21 years, in mothers with gestational hypertension was 24.44 years, in preeclampsia was 24.42 years and in eclampsia was 22 years. The mean systolic blood pressure in normal mothers was $119.67 \mathrm{~mm} \mathrm{Hg}$ in mothers with gestational hypertension was $139.38 \mathrm{~mm} \mathrm{Hg}$, in preeclampsia was $151.69 \mathrm{mmHg}$ and in eclampsia $169.25 \mathrm{mmhg}$. The mean DBP in normal mothers was 80.16 $\mathrm{mmHg}$, in mothers with gestational hypertension was $98.13 \mathrm{Hg}$, in preeclampsia was $98.38 \mathrm{~mm} \mathrm{Hg}$ and in Eclampsia was $107.75 \mathrm{mmHg}$.

Mean MAP in normal mothers as $93.33 \mathrm{~mm} \mathrm{Hg}$, in mothers with gestational hypertension was 111.88 $\mathrm{mmHg}$, in preeclampsia was $118.72 \mathrm{mmHg}$ and in eclampsia was $128.25 \mathrm{mmHg}$. The mean SBP, DBP and MAP were significantly higher in cases than in controls.

Mean plasma homocysteine in normal mothers was $10.50 \mathrm{~mol} / \mathrm{L}$, in mothers with gestational hypertension was $16.43 \mathrm{~mol} / \mathrm{L}$, in preeclampsia was $20.23 \mathrm{~mol} / \mathrm{L}$ and in Eclampsia was $20.10 \mathrm{~mol} / \mathrm{L}$. Mean Plasma homocysteine levels were found to be significantly higher in cases compared to controls. Several studies $(4,5,6)$ also published results which correlated with the results of the present study. Amir et al., 2006 (4) reported that the fasting plasma homocysteine levels were higher in patients with preeclampsia when compared to normotensive pregnant women. This observation has been highlighted by Mansour et al, 2011 (7), where serum homocysteine was found to be 3 folds higher in patients with severe preeclampsia

There was a significant association between live births and gestational hypertension $(\mathrm{p}<0.05)$. The higher the numbers of live children lower the occurrences of gestational hypertension. There was significant association between family history of cardiovascular disease and gestational hypertension $(\mathrm{p}<0.001)$. There was a significant association between plasma homocysteine levels and gestational hypertension $(\mathrm{p}<0.001)$

Ingec et al in 2005 (6) showed that homocysteine concentration in severe preeclamptic and eclamptic women were significantly higher than mild preeclamptic and normotensive women concluding that elevated plasma homocysteine levels in early pregnancy can increase the risk of developing severe preeclampsia which correlated with the results of the present study. Also, recent study has highlighted that the higher levels of homocysteine is associated with severity of hypertension and also associated maternal complications such as abruption, retinopathy, MODS, eclampsia and maternal mortality (9)

El abd et al in 2009 (10) conducted a case control study which highlighted the positive correlation between plasma homocysteine levels and SBP, DBP and MAP and at the same time disproved its association with age. Vincent et al in 2009 (11), also established the positive correlation between the mean homocysteine levels and gestational hypertension, and the levels are proportional to the severity of hypertension. The results of the present study also correlated with the established results which suggested that MAP, SBP, DBP were higher in patients with elevated plasma homocysteine levels.

\section{Conclusion}

To conclude, in our study it has been established that a positive relationship exists between plasma homocysteine levels and gestational hypertension. Also, it has been highlighted that the levels of plasma homocysteine are higher in patients with positive family history of cardiovascular disease, and higher homocysteine levels indicate severe disease.Increased levels of plasma homocysteine in pregnant women could be used as a potential marker for predicting gestational hypertension and its severity.

Table 1Descriptive statistics

\begin{tabular}{|l|l|l|l|l|l|}
\hline & N & Minimum & Maximum & Mean & \\
\hline Age & 111 & 18 & 38 & 23.59 & 3.602 \\
\hline SBP & 111 & 110 & 180 & 133.59 & 17.666 \\
\hline DBP & 111 & 70 & 130 & 89.01 & 15.523 \\
\hline Mean arterial pressure & 111 & 83.33 & 176.67 & 104.46 & 15.07 \\
\hline Birth weight of child & 111 & 1.4 & 3.7 & 2.8 & 0.34 \\
\hline P. Homocysteine & 111 & 6 & 54 & 14.32 & 7.899 \\
\hline Valid N (List wise) & 111 & & & & \\
\hline
\end{tabular}

Table 2Association between age and gestational hypertension

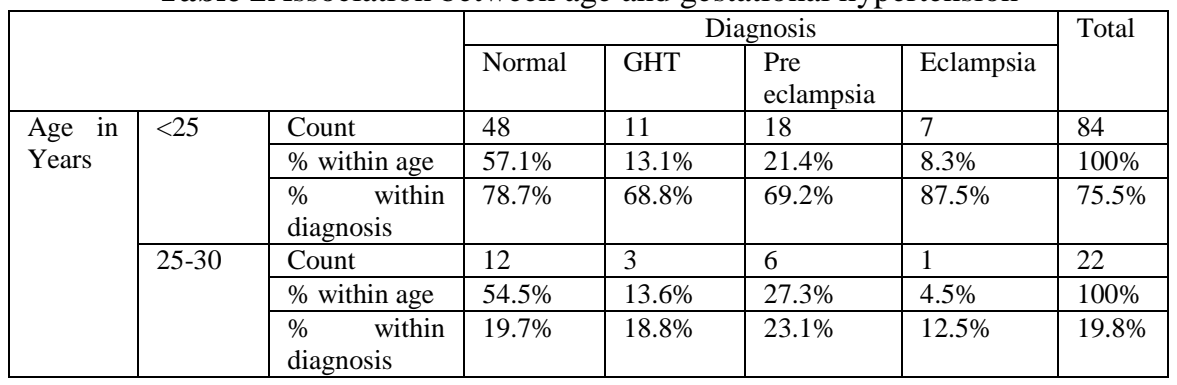




\begin{tabular}{|c|c|c|c|c|c|c|c|}
\hline \multirow[t]{6}{*}{ Total } & \multirow[t]{3}{*}{$>30$} & Count & 1 & 2 & 2 & 0 & 5 \\
\hline & & $\%$ within age & $20 \%$ & $40 \%$ & $40 \%$ & $0 \%$ & $100 \%$ \\
\hline & & $\begin{array}{l}\% \text { within } \\
\text { diagnosis }\end{array}$ & $1.6 \%$ & $12.5 \%$ & $7.7 \%$ & $0 \%$ & $4.5 \%$ \\
\hline & \multirow[t]{3}{*}{ Count } & Count & 61 & 16 & 26 & 8 & 111 \\
\hline & & $\%$ within age & $55 \%$ & $14.4 \%$ & $23.4 \%$ & $7.2 \%$ & $100 \%$ \\
\hline & & $\begin{array}{l}\% \text { within } \\
\text { diagnosis }\end{array}$ & $100 \%$ & $100 \%$ & $100 \%$ & $100 \%$ & $100 \%$ \\
\hline
\end{tabular}

Table 3Association between parity and gestational hypertension

\begin{tabular}{|c|c|c|c|c|c|c|c|}
\hline & \multicolumn{4}{|c|}{ Diagnosis } & \multirow[t]{2}{*}{ Total } \\
\hline & & & Normal & GHT & Pre clampsia & Eclampsia & \\
\hline \multirow[t]{12}{*}{ Parity } & \multirow[t]{3}{*}{ One } & Count & 32 & 11 & 16 & 7 & 66 \\
\hline & & $\begin{array}{ll}\% & \text { within } \\
\text { parity } & \end{array}$ & $48.5 \%$ & $16.7 \%$ & $24.2 \%$ & $10.6 \%$ & $100 \%$ \\
\hline & & $\begin{array}{l}\% \text { within } \\
\text { diagnosis }\end{array}$ & $52.5 \%$ & $68.8 \%$ & $61.5 \%$ & $87.5 \%$ & $59.5 \%$ \\
\hline & \multirow[t]{3}{*}{ Two } & Count & 25 & 5 & 5 & 1 & 36 \\
\hline & & $\begin{array}{ll}\% & \text { within } \\
\text { parity } & \end{array}$ & $69.4 \%$ & $13.9 \%$ & $13.9 \%$ & $2.8 \%$ & $100 \%$ \\
\hline & & $\begin{array}{l}\% \text { within } \\
\text { diagnosis }\end{array}$ & $41 \%$ & $31.3 \%$ & $19.2 \%$ & $12.5 \%$ & $32.4 \%$ \\
\hline & \multirow[t]{3}{*}{ Three } & Count & 3 & 0 & 4 & 0 & 7 \\
\hline & & $\begin{array}{ll}\% & \text { within } \\
\text { parity } & \end{array}$ & $42.9 \%$ & $0 \%$ & $57.1 \%$ & $0 \%$ & $100 \%$ \\
\hline & & $\begin{array}{l}\% \text { within } \\
\text { diagnosis }\end{array}$ & $4.9 \%$ & $0 \%$ & $15.4 \%$ & $0 \%$ & $6.3 \%$ \\
\hline & \multirow[t]{3}{*}{ Four } & Count & 1 & 0 & 1 & 0 & 2 \\
\hline & & $\begin{array}{l}\% \\
\text { parity }\end{array}$ & $50 \%$ & $0 \%$ & $50 \%$ & $0 \%$ & $100 \%$ \\
\hline & & $\begin{array}{l}\% \text { within } \\
\text { diagnosis }\end{array}$ & $1.6 \%$ & $0 \%$ & $3.8 \%$ & $0 \%$ & $1.8 \%$ \\
\hline \multirow[t]{3}{*}{ Total } & \multirow[t]{3}{*}{ count } & Count & 61 & 16 & 26 & 8 & 111 \\
\hline & & $\begin{array}{ll}\% & \text { within } \\
\text { parity } & \end{array}$ & $56 \%$ & $14.4 \%$ & $23.4 \%$ & $7.2 \%$ & $100 \%$ \\
\hline & & $\begin{array}{l}\% \text { within } \\
\text { diagnosis }\end{array}$ & $100 \%$ & $100 \%$ & $100 \%$ & $100 \%$ & $100 \%$ \\
\hline
\end{tabular}

Table 4Association between no. of live births and gestational hypertension

\begin{tabular}{|c|c|c|c|c|c|c|c|}
\hline & \multicolumn{4}{|c|}{ Diagnosis } & \multirow[t]{2}{*}{ Total } \\
\hline & & & Normal & GHT & $\begin{array}{l}\text { Pre } \\
\text { eclampsia }\end{array}$ & Eclampsia & \\
\hline \multirow{15}{*}{$\begin{array}{l}\text { Parity } \\
\text { Total }\end{array}$} & \multirow[t]{3}{*}{ nil } & Count & 0 & 3 & 1 & 2 & 6 \\
\hline & & $\begin{array}{l}\% \text { within live } \\
\text { births }\end{array}$ & $0 \%$ & $50 \%$ & $16.7 \%$ & $33.3 \%$ & $100 \%$ \\
\hline & & $\begin{array}{ll}\% & \text { within } \\
\text { diagnosis } & \\
\end{array}$ & $0 \%$ & $18.8 \%$ & $3.8 \%$ & $25 \%$ & $5.4 \%$ \\
\hline & \multirow[t]{3}{*}{ One } & Count & 33 & 7 & 17 & 5 & 62 \\
\hline & & $\begin{array}{l}\% \text { within live } \\
\text { births }\end{array}$ & $53.2 \%$ & $11.3 \%$ & $27.4 \%$ & $8.1 \%$ & $100 \%$ \\
\hline & & $\begin{array}{ll}\% & \text { within } \\
\text { diagnosis } & \end{array}$ & $54.1 \%$ & $43.8 \%$ & $65.4 \%$ & $2.5 \%$ & $55.9 \%$ \\
\hline & \multirow[t]{3}{*}{ Two } & Count & 24 & 4 & 4 & 1 & 33 \\
\hline & & $\begin{array}{l}\% \text { within live } \\
\text { births }\end{array}$ & $72.7 \%$ & $12.1 \%$ & $12.1 \%$ & $3 \%$ & $100 \%$ \\
\hline & & $\begin{array}{ll}\% & \text { within } \\
\text { diagnosis } & \\
\end{array}$ & $39.3 \%$ & $25 \%$ & $15.4 \%$ & $12.5 \%$ & $29.7 \%$ \\
\hline & \multirow[t]{3}{*}{ Three } & Count & 3 & 2 & 3 & 0 & 8 \\
\hline & & $\begin{array}{l}\% \text { within live } \\
\text { births }\end{array}$ & $37.5 \%$ & $25 \%$ & $37.5 \%$ & $0 \%$ & $100 \%$ \\
\hline & & $\begin{array}{ll}\% & \text { within } \\
\text { diagnosis } & \\
\end{array}$ & $4.9 \%$ & $12.5 \%$ & $11.5 \%$ & $0 \%$ & $7.2 \%$ \\
\hline & \multirow[t]{3}{*}{ Four } & Count & 1 & 0 & 1 & 0 & 2 \\
\hline & & $\begin{array}{l}\% \text { within live } \\
\text { births }\end{array}$ & $50 \%$ & $0 \%$ & $50 \%$ & $0 \%$ & $100 \%$ \\
\hline & & $\begin{array}{ll}\% & \text { within } \\
\text { diagnosis } & \\
\end{array}$ & $1.6 \%$ & $0 \%$ & $3.8 \%$ & $0 \%$ & $1.8 \%$ \\
\hline \multirow[t]{3}{*}{ Total } & & Count & 61 & 16 & 26 & 8 & 111 \\
\hline & & $\begin{array}{l}\text { \% within live } \\
\text { births }\end{array}$ & $55 \%$ & $14.4 \%$ & $23.4 \%$ & $7.2 \%$ & $100 \%$ \\
\hline & & $\%$ with diagnosis & $100 \%$ & $100 \%$ & $100 \%$ & $100 \%$ & $100 \%$ \\
\hline
\end{tabular}


Study Of Relationship Between Plasma Homocysteine Levels And Gestationalhypertension

Table 5Association between family history of cardiovascular disease and gestational hypertension

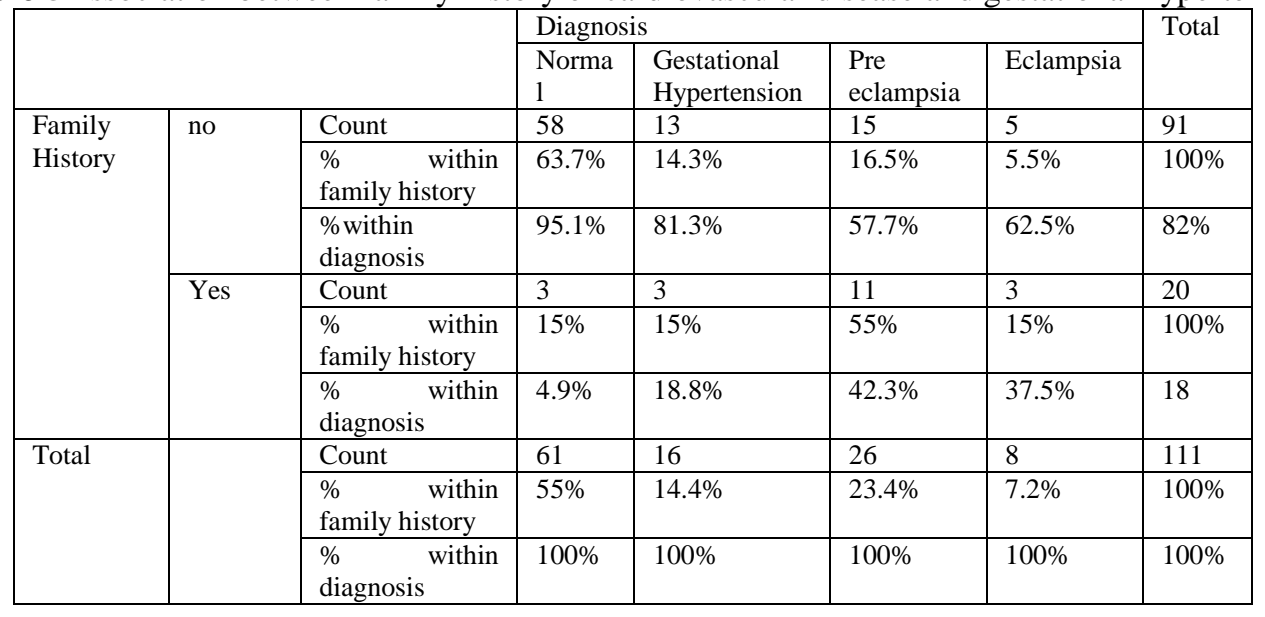

Table 6Association between plasma homocysteine levels and gestational hypertension

\begin{tabular}{|c|c|c|c|c|c|c|c|}
\hline & \multicolumn{5}{|c|}{ Diagnosis } \\
\hline & & & Normal & $\begin{array}{l}\text { Gestational } \\
\text { Hypertension }\end{array}$ & Preeclampsia & Eclampsia & Total \\
\hline \multirow{6}{*}{$\begin{array}{l}\text { Plasma } \\
\text { homocysteine }\end{array}$} & \multirow{3}{*}{ Normal } & Count & 57 & 8 & 9 & 2 & 76 \\
\hline & & $\begin{array}{l}\% \text { within } \\
\text { plasma } \\
\text { homocystein } \\
\text { e }\end{array}$ & $75 \%$ & $10.5 \%$ & $11.8 \%$ & $2.6 \%$ & $100 \%$ \\
\hline & & $\begin{array}{l}\text { \%within } \\
\text { diagnosis }\end{array}$ & $93.4 \%$ & $50 \%$ & $34.6 \%$ & $25 \%$ & $68.5 \%$ \\
\hline & \multirow[t]{3}{*}{ Abnormal } & Count & 4 & 8 & 17 & 6 & 35 \\
\hline & & $\begin{array}{l}\% \text { within } \\
\text { plasma } \\
\text { homocystein } \\
\text { e }\end{array}$ & $11.4 \%$ & $22.9 \%$ & $48.6 \%$ & $17.1 \%$ & $100 \%$ \\
\hline & & $\begin{array}{l}\% \text { within } \\
\text { diagnosis }\end{array}$ & $6.6 \%$ & $50 \%$ & $65.4 \%$ & $75 \%$ & $31.5 \%$ \\
\hline \multirow[t]{3}{*}{ Total } & & Count & 61 & 16 & 26 & 8 & 111 \\
\hline & & $\begin{array}{l}\text { \%within pl. } \\
\text { homocystein } \\
\text { e }\end{array}$ & $55 \%$ & $14.4 \%$ & $23.4 \%$ & $7.2 \%$ & $100 \%$ \\
\hline & & $\begin{array}{l}\% \text { within } \\
\text { diagnosis }\end{array}$ & $100 \%$ & $100 \%$ & $100 \%$ & $100 \%$ & $100 \%$ \\
\hline
\end{tabular}

Table 7Correlation between factors

\begin{tabular}{|c|c|c|c|c|c|c|c|}
\hline & & Parity & $\begin{array}{l}\text { Family } \\
\text { History }\end{array}$ & MAP & SBP & DBP & $\begin{array}{l}\text { P. } \\
\text { Homocysteine }\end{array}$ \\
\hline \multirow[t]{3}{*}{ Parity } & $\begin{array}{l}\text { Pearson } \\
\text { correlation }(\mathrm{r})\end{array}$ & 1 & 098 & .042 & .089 & .111 & .010 \\
\hline & $\begin{array}{l}\text { Significance } \\
\text { (p) }\end{array}$ & & .306 & .663 & .353 & .244 & .919 \\
\hline & $\mathrm{N}$ & 111 & 111 & 111 & 111 & 111 & 111 \\
\hline \multirow[t]{3}{*}{ Family History } & $\begin{array}{l}\text { Pearson } \\
\text { correlation (r) }\end{array}$ & .098 & 1 & .360 & 438 & .276 & .181 \\
\hline & Significance(p) & .306 & & .000 & .000 & .003 & .058 \\
\hline & $\mathrm{N}$ & 111 & 111 & 111 & 111 & 111 & 111 \\
\hline \multirow[t]{3}{*}{ MAP } & $\begin{array}{l}\text { Pearson } \\
\text { correlation (r) }\end{array}$ & 042 & .306 & 1 & .872 & .960 & .447 \\
\hline & $\begin{array}{l}\text { Significance } \\
\text { (p) }\end{array}$ & .663 & .000 & & .000 & .000 & .000 \\
\hline & $\mathrm{N}$ & 111 & 111 & 111 & 111 & 111 & 111 \\
\hline \multirow[t]{3}{*}{$\overline{\mathrm{SBP}}$} & $\begin{array}{l}\text { Pearson } \\
\text { Correlation (r) }\end{array}$ & .089 & 438 & .872 & 1 & .701 & .559 \\
\hline & $\begin{array}{l}\text { Significance } \\
\text { (p) }\end{array}$ & .353 & .000 & .000 & & .000 & .000 \\
\hline & $\mathrm{N}$ & 111 & 111 & 111 & 111 & 111 & 111 \\
\hline \multirow[t]{2}{*}{ DBP } & $\begin{array}{l}\text { Peason } \\
\text { correlation }(\mathrm{r})\end{array}$ & .111 & .276 & .960 & .701 & 1 & .334 \\
\hline & $\begin{array}{l}\text { Significance } \\
\text { (p) }\end{array}$ & .244 & .003 & .000 & .000 & & .000 \\
\hline
\end{tabular}




\begin{tabular}{|l|l|l|l|l|l|l|l|}
\hline & $\mathrm{N}$ & 111 & 111 & 111 & 111 & 111 & 111 \\
\hline P.Homocysteine & $\begin{array}{l}\text { Pearson } \\
\text { correlation (r) }\end{array}$ & 010 & .181 & .477 & .559 & .334 & 1 \\
\hline & $\begin{array}{l}\text { Significance } \\
(\mathrm{p})\end{array}$ & .919 & .058 & .000 & .000 & .000 & \\
\hline & $\mathrm{N}$ & 111 & 111 & 111 & 111 & 111 & 111 \\
\hline
\end{tabular}

Table 8Association between family history of cardiovascular disease and plasma homocysteine

\begin{tabular}{|c|c|c|c|c|c|}
\hline & & & \multicolumn{2}{|c|}{ Plasma Homocysteine } & \multirow[t]{2}{*}{ Total } \\
\hline & & & Normal & Abnormal & \\
\hline \multirow[t]{6}{*}{ Family History } & \multirow[t]{3}{*}{ No } & Count & 66 & 25 & 91 \\
\hline & & $\%$ within family history & $72.5 \%$ & $27.5 \%$ & $100 \%$ \\
\hline & & $\begin{array}{l}\% \text { within } \\
\text { Homocysteine }\end{array}$ & $86.8 \%$ & $71.4 \%$ & $82 \%$ \\
\hline & \multirow[t]{3}{*}{ Yes } & Count & 10 & 10 & 20 \\
\hline & & $\%$ within Family History & $50 \%$ & $50 \%$ & $100 \%$ \\
\hline & & 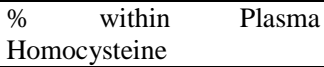 & $13.2 \%$ & $28.6 \%$ & $18 \%$ \\
\hline \multirow[t]{3}{*}{ Total } & & Count & 76 & 35 & 111 \\
\hline & & $\%$ within Family History & $68.5 \%$ & $31.5 \%$ & 100 \\
\hline & & $\begin{array}{l}\% \text { within } \\
\text { Homocysteine }\end{array}$ & $100 \%$ & $100 \%$ & $100 \%$ \\
\hline
\end{tabular}

\section{References}

[1]. Report of the National high blood pressure education program working group on high blood pressure in pregnancy. Am $\mathbf{J}$ obstet gynecol. 2000; 183(1):s1-s22.

[2]. Desai P, Rathod S. Garge V, Mansuri Z. Evaluation of pro-oxidants \& antioxidants in pre-eclampsia Jr. O\&G India 2003: 53(5), 445-448

[3]. Sheppard BL, Bonnar J. An ultrastructural study of uteroplacental spiral arteries in hypertensive and normotensive pregnancy and fetal growth retardation. Br J obstet gynecol. 88:695-705, 1981

[4]. Amir, Ahmed, Shamsi, Ul-Ain, sultana. Elevated circulating homocysteine levels in patients with mild preeclampsia. Esculapio journal of SIMS 2006;36-38

[5]. Lopez, Vilaseca, Lailla. Plasma total Homocysteine in uncomplicated pregnancy and preeclampsia. Eur J Obstetgynecolreprod boil. 2003 May 1; 108 (1):45-9

[6]. Raijmakers, Zusterzeel, Steegers, Peters: Hyperhomocysteinemia : a risk factor for preeclampsia. Eur J Obstetgynecolreprod boil. 2001 Apr ; 95(2):226-8

[7]. Mansour A, Harb H and Abdelhafeez M, Diagnostic value of Homocysteine and other preeclampsia markers:Relationship with severity, International Journal of Biological Chemistry, 2011, 5: 227-237

[8]. Ingec M, Borekci B, Kadanali S, Tohoku J. Elevated homocysteine concentrations in severe preeclampsia and Eclampsia. 2005; 206:225-31.

[9]. Maru L, Verma M, Jinsiwale N, Homocysteine as predictgive marker for pregnancy induced hypertension-A comparative study of Homocysteine levels in Normal Versus Patients of PIH and its complications, Journal of Obstetrics and Gynaecology of India, October 2016, Vol 66 (1), pp 167-171.

[10]. E1-Abd, Mellies, Kassem, Youssry, Risk, Homocysteine level as a marker in cases of early onset severe preeclampsia. Bull Alex facmed 45 No. 1, 2009.

[11]. Vincent, Alani, Adewumi, Olalekan. Homocysteine levels in Nigerian women with preeclampsia / eclampsia. Sierra leone journal of biomedical research vol 1(1) pp55-60. August 2009. 